\title{
Cascading $\mathrm{g}-\mathrm{C}_{3} \mathrm{~N}_{4}$ and Peroxygenases for Selective Oxyfunctionalization Reactions
}

Morten M. C. H. van Schie, ${ }^{*}{ }^{\dagger}$ Wuyuan Zhang, ${ }^{\dagger}$ Florian Tieves, ${ }^{\dagger}$ Da Som Choi, ${ }^{\ddagger}$ Chan Beum Park, ${ }^{\ddagger}$ Bastien O. Burek, ${ }^{\S}$ Jonathan Z. Bloh, ${ }^{\S}$ Isabel W. C. E. Arends, $"$ Caroline E. Paul, ${ }^{\dagger}{ }^{\circledR}$ Miguel Alcalde, ${ }^{\perp}$ and Frank Hollmann ${ }^{*} \dagger$ (ं)

${ }^{\dagger}$ Department of Biotechnology, Delft University of Technology, van der Maasweg 9, 2629HZ Delft, The Netherlands

${ }^{\ddagger}$ Department of Materials Science and Engineering, Korea Advanced Institute of Science and Technology (KAIST), 335 Science Road, Daejeon 305-701, Republic of Korea

${ }^{\S}$ DECHEMA Forschungsinstitut, Theodor-Heuss-Allee 25, 60486 Frankfurt am Main, Germany

"University of Utrecht, Faculty of Science, Budapestlaan 6, 3584 CD Utrecht, The Netherlands

${ }^{\perp}$ Department of Biocatalysis, Institute of Catalysis, CSIC, 28049 Madrid, Spain

\section{Supporting Information}

ABSTRACT: Peroxygenases are very interesting catalysts for specific oxyfunctionalization chemistry. Instead of relying on complicated electron transport chains, they rely on simple hydrogen peroxide as the stoichiometric oxidant. Their poor robustness against $\mathrm{H}_{2} \mathrm{O}_{2}$ can be addressed via in situ generation of $\mathrm{H}_{2} \mathrm{O}_{2}$. Here we report that simple graphitic carbon nitride $\left(\mathrm{g}-\mathrm{C}_{3} \mathrm{~N}_{4}\right)$ is a promising photocatalyst to drive

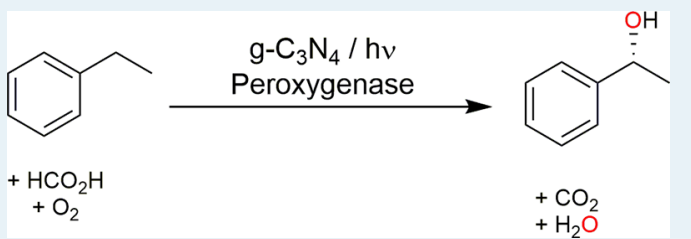
peroxygenase-catalyzed hydroxylation reactions. The system has been characterized by outlining not only its scope but also its current limitations. In particular, spatial separation of the photocatalyst from the enzyme is shown as a solution to circumvent the undesired inactivation of the biocatalyst. Overall, very promising turnover numbers of the biocatalyst of more than 60.000 have been achieved.

KEYWORDS: cascade reactions, enzyme catalysis, oxidation, oxyfunctionalization, photocatalysis

elective oxyfunctionalization of nonactivated $\mathrm{sp}^{3}$ carbonhydrogen bonds is a challenge in organic synthesis.

Scheme 1. Photoenzymatic Hydroxylation of Ethyl Benzene Combining Heterogeneous Photocatalysts for the Reductive Activation of $\mathrm{O}_{2}$ to $\mathrm{H}_{2} \mathrm{O}_{2}$ with a Peroxygenase-Catalyzed Oxyfunctionalization Reaction

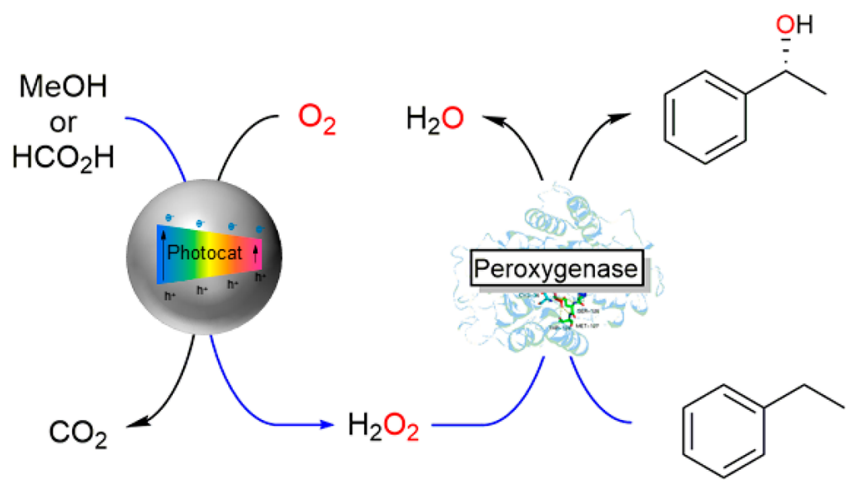

Catalysts exhibiting both high oxidation potential and high selectivity are rarely found. ${ }^{1}$ In this respect, so-called unspecific peroxygenases (UPOs), next to the established P450 monooxygenases and some other nonheme-monooxygenases, ${ }^{2}$ have attracted considerable interest. $^{3-5}$ Monooxygenases generate their catalytically active species through reductive activation of molecular oxygen. For this, monooxygenases rely on complex electron transport chains delivering the reducing equivalents from $\mathrm{NAD}(\mathrm{P}) \mathrm{H}$ to the monooxygenases' active sites. This complicates their practical use. Furthermore, quite frequently, a significant portion of the reducing equivalents is uncoupled into a futile reaction with molecular oxygen, thereby wasting valuable reducing equivalents and generating hazardous reactive oxygen species. ${ }^{6}$

UPOs do not rely on the aforementioned electron transport chains but rather use simple $\mathrm{H}_{2} \mathrm{O}_{2}$ as the oxidant. This makes UPOs very attractive from a preparative point-of-view. $\mathrm{H}_{2} \mathrm{O}_{2}$, however, is also a potent inhibitor of peroxygenases as already small excesses oxidatively inactivate the prosthetic heme group. ${ }^{7}$ Generating $\mathrm{H}_{2} \mathrm{O}_{2}$ in situ through catalytic reduction of $\mathrm{O}_{2}$ is the most common approach to alleviate the inactivation issue. ${ }^{8}$ In essence, these systems provide $\mathrm{H}_{2} \mathrm{O}_{2}$ at rates that enable efficient peroxygenase activity while minimizing the $\mathrm{H}_{2} \mathrm{O}_{2}$-related inactivation. These methods

Received: April 1, 2019

Revised: June 30, 2019

Published: July 9, 2019 

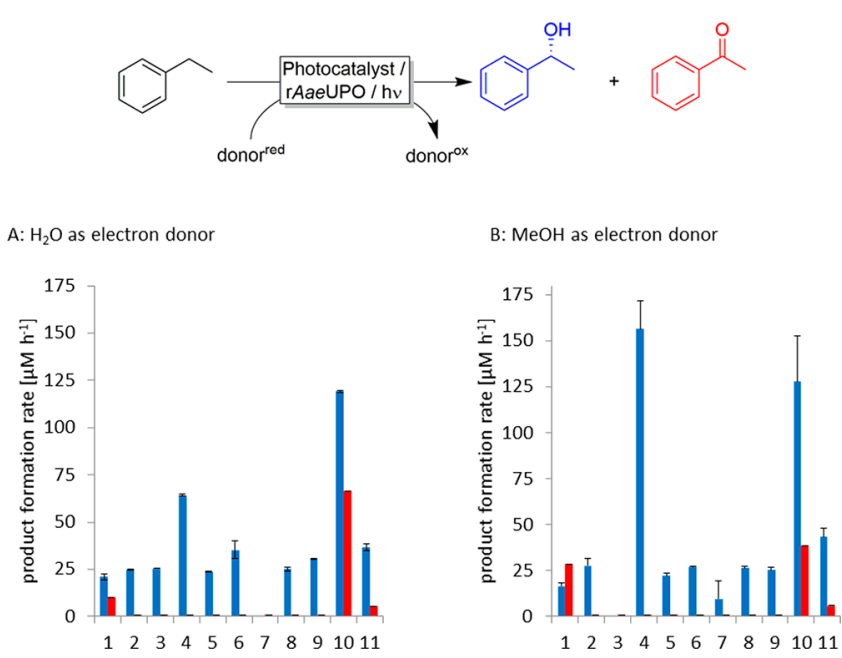

Figure 1. Performance of several heterogeneous photocatalysts to promote rAaeUPO-catalyzed oxyfunctionalization, forming phenyl ethanol (blue) and the overoxidation product acetophenone (red), in absence (left) or presence (right) of methanol. Conditions: $5 \mathrm{mg}$ $\mathrm{mL}^{-1}$ heterogeneous catalyst, $50 \mathrm{mM}$ ethylbenzene, 0 or $250 \mathrm{mM}$ methanol, and $100 \mathrm{nM}$ rAaeUPO in a $100 \mathrm{mM}$ phosphate buffer at

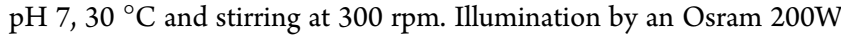
light bulb for $30 \mathrm{~min}$. Reactions were performed in independent duplicates. 1: $\mathrm{Au}-\mathrm{BiVO}_{4} ;{ }^{40}$ 2: $\mathrm{Co}_{3} \mathrm{O}_{4}$ (quantum dots) ${ }^{41}$ 3: $\mathrm{Co}_{4}\left(\mathrm{H}_{2} \mathrm{O}\right)_{2}\left(\mathrm{~W}_{9} \mathrm{O}_{34}\right)_{2} ;{ }^{42}$ 4: $\mathrm{Pt}_{-} \mathrm{TiO}_{2}$ (Rutile); ${ }^{43}$ 5: $\mathrm{MnO}$ (on Faujasite); ${ }^{44}$ 6: $\mathrm{Co}^{-\mathrm{TiO}_{2}} ;{ }^{45}$ 7: $\mathrm{MnO}$ (nanowires); ${ }^{46}$ 8: $\mathrm{Ir} @ \mathrm{SiO}_{2} ;$ 9: $\mathrm{Fe}_{2} \mathrm{O}_{3} ;{ }^{47}$ 10: $\mathrm{g}^{-\mathrm{C}_{3} \mathrm{~N}_{4} ; 11: \mathrm{ZnO} \text { (nanoclusters). }}{ }^{48}$ comprise a range of chemical, ${ }^{9-15}$ electrochemical, ${ }^{16-21}$ enzymatic, $^{22-26}$ and photocatalytic ${ }^{27-34}$ approaches.

The latter is particularly interesting as it, in principle, enables using light energy to access simple sacrificial electron donors to drive the reduction of $\mathrm{O}_{2}$ to $\mathrm{H}_{2} \mathrm{O}_{2}$. To make light energy available for this reaction, a photosensitizer (or photocatalyst) is necessary. Both homogeneously dissolved molecular and semiconductor-based solid material photocatalysts have been evaluated. While the first often suffer from issues of photobleaching and inactivation, the latter excel by their high robustness and reusability. So far, mainly $\mathrm{TiO}_{2}$-based semiconductor photocatalysts have been evaluated to promote peroxygenase-catalyzed oxyfunctionalization reactions.

Therefore, we set out to investigate a broader set of (in)organic photocatalyst systems ${ }^{35}$ to promote peroxygenasecatalyzed reactions (Scheme 1).

We chose the selective hydroxylation of ethylbenzene to (R)-1-phenyl ethanol catalyzed by the peroxygenase from Agrocybe aegerita (rAaeUPO) as the model reaction. ${ }^{36-39}$

In a first set of experiments, we evaluated several reported and/or commercially available heterogeneous photocatalysts (Figure 1) with respect to their ability to form $\mathrm{H}_{2} \mathrm{O}_{2}$; particularly, we investigated their performance in the envisioned photoenzymatic cascade transforming ethylbenzene to $(R)$-1-phenyl ethanol (Figure 1). It is worth mentioning that in the absence of the photocatalysts or light, no product formation was observed. In the absence of rAaeUPO, upon
A

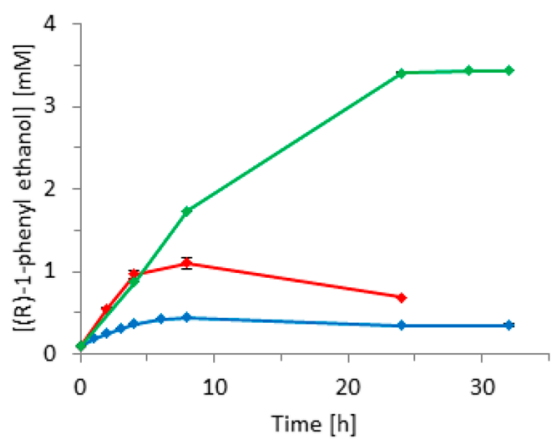

C

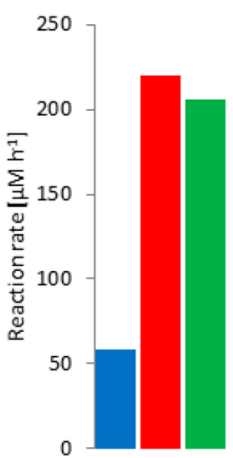

D

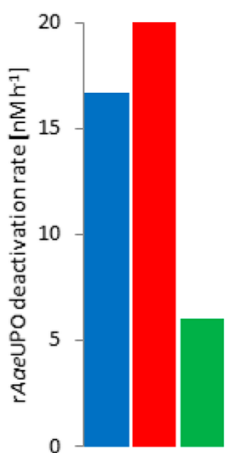

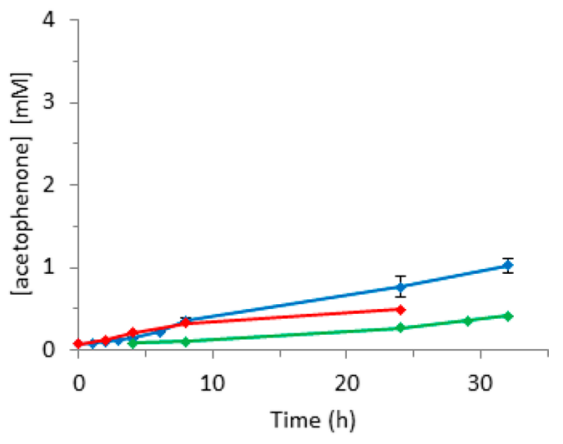

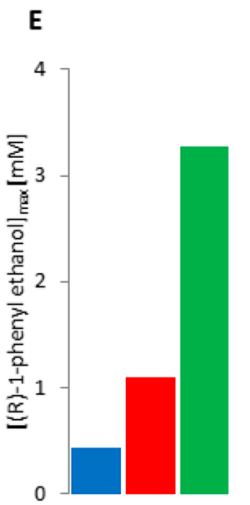

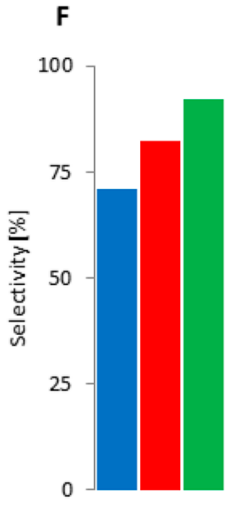

Figure 2. $\mathrm{g}-\mathrm{C}_{3} \mathrm{~N}_{4}$ as photocatalyst to promote $\mathrm{rAaeUPO}$-catalyzed hydroxylation of ethylbenzene in the absence of external electron donors (blue), or $250 \mathrm{mM}$ methanol (red) or $250 \mathrm{mM}$ formate (green). (A) Time course of (R)-1-phenyl ethanol formation and (B) time course of acetophenone formation. From these time courses, parameters such as reaction rate (C), rAaeUPO inactivation rate (D), maximal product concentration (E), and selectivity (F) were calculated. General conditions: $[\mathrm{rAaeUPO}]=100 \mathrm{nM}$, [ethylbenzene] $=50 \mathrm{mM},\left[\mathrm{g}-\mathrm{C}_{3} \mathrm{~N}_{4}\right]=5 \mathrm{mg} \mathrm{mL}{ }^{-1}, \mathrm{KPi}$ buffer $\mathrm{pH} 7.0$ $(100 \mathrm{mM}), 30{ }^{\circ} \mathrm{C}$, magnetic stirring at $600 \mathrm{rpm}$, illumination by an Osram $200 \mathrm{~W}$ light bulb. Reactions were performed in independent duplicates. 
A

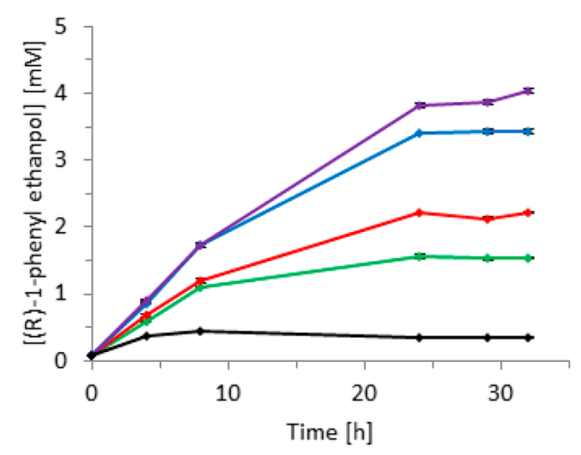

C

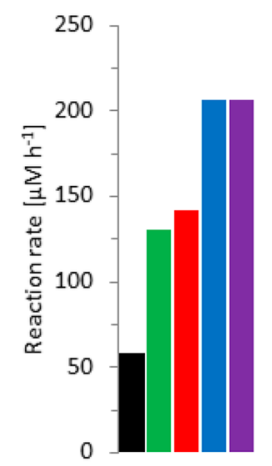

D

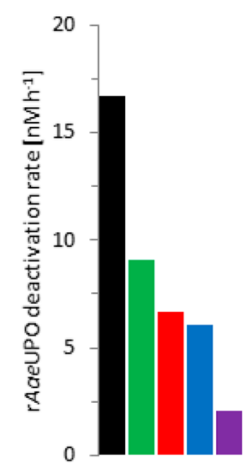

B

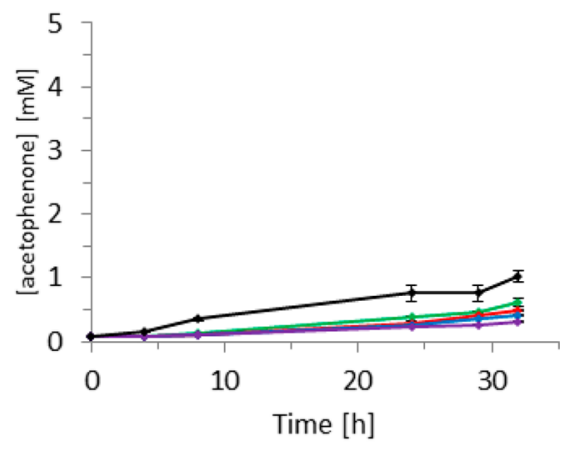

E

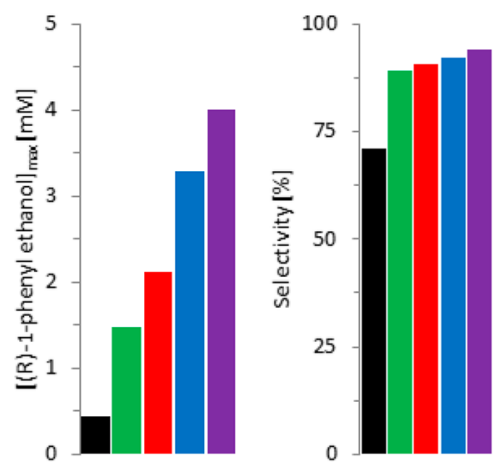

Figure 3. Influence of the formate concentration on the performance of the photoenzymatic hydroxylation of ethylbenzene. (A) Time course of $(R)$-1-phenyl ethanol formation and (B) time course of acetophenone formation. From these time courses, parameters such as reaction rate (C), rAae UPO inactivation rate (D), maximal product concentration (E), and selectivity (F) were calculated. $\left[\mathrm{HCO}_{2}^{-}\right]=0 \mathrm{mM}(\mathrm{black}), 50 \mathrm{mM}$ (green), $100 \mathrm{mM}$ (red), $250 \mathrm{mM}$ (blue) or $500 \mathrm{mM}$ (purple). General conditions: [rAaeUPO] $=100 \mathrm{nM}$, [ethylbenzene] $=50 \mathrm{mM}$, [g-C $\mathrm{N}_{4}$ ] $=5$ $\mathrm{mg} \mathrm{mL}{ }^{-1}$, KPi buffer $\mathrm{pH} 7.0(100 \mathrm{mM}), 30^{\circ} \mathrm{C}$, magnetic stirring at $600 \mathrm{rpm}$, illumination by an Osram $200 \mathrm{~W}$ light bulb. Reactions were performed in independent duplicates.

prolonged reaction times, traces of racemic product and the overoxidation product were observed in some cases.

Almost all heterogeneous photocatalysts tested enabled the desired reaction both in the presence and absence of an extra electron donor (methanol). However, reaction rates tended to be significantly lower in experiments where methanol was absent. In the absence of methanol, it may be assumed that water was the primary reductant. ${ }^{49}$ As water oxidation is thermodynamically more challenging than methanol oxidation, this explains the generally lower product formation rates in the absence of methanol. In some cases, significant amounts of acetophenone were found along with the desired ( $R$ )-1-phenyl ethanol. We attribute this to the oxidation of the desired product by the photocatalysts. ${ }^{50}$ Platinum loaded titanium oxide $\left(\mathrm{Pt}-\mathrm{TiO}_{2}\right)$ and graphitic carbon nitride $\left(\mathrm{g}-\mathrm{C}_{3} \mathrm{~N}_{4}\right)$ stood out in terms of product formation rate. For reasons of ease of preparation, we further focused on $\mathrm{g}-\mathrm{C}_{3} \mathrm{~N}_{4}$ as photocatalyst. Furthermore, $\mathrm{g}-\mathrm{C}_{3} \mathrm{~N}_{4}$ has previously been reported to be highly selective for $\mathrm{H}_{2} \mathrm{O}_{2}$ over other (partially reduced) reactive oxygen species. $^{51}$

Figure 2 shows the overall product formation of $\mathrm{g}-\mathrm{C}_{3} \mathrm{~N}_{4}$ using either water (blue), methanol (red), or formate (green) as sacrificial electron donor to promote the photoenzymatic hydroxylation of ethylbenzene. Assumptions made to obtain the bar-graphs can be found in the experimental section.

From a conceptual and an environmental point-of-view, water would have been the most desirable source of reducing equivalents. However, this system fell back in terms of catalytic rate and selectivity compared with the use of methanol or formate as sacrificial electron donor. In comparative experiments, illuminating $\mathrm{g}-\mathrm{C}_{3} \mathrm{~N}_{4}$ in phosphate buffer gave negligible $\mathrm{H}_{2} \mathrm{O}_{2}$ formation rates $\left(<1.0 \mu \mathrm{M} \mathrm{h}^{-1}\right)$, which more than doubled to $2.0( \pm 0.02) \mu \mathrm{M} \mathrm{min}{ }^{-1}$ upon addition of formate. Similar observations have been made before for $\mathrm{TiO}_{2} \cdot{ }^{52}$ Since g- $\mathrm{C}_{3} \mathrm{~N}_{4}$ is not an efficient water oxidation catalyst, ${ }^{52}$ other molecules are more likely to serve as reductants in the $\mathrm{g}-\mathrm{C}_{3} \mathrm{~N}_{4}$ catalyzed reduction of $\mathrm{O}_{2}$. Both ethylbenzene and phenyl ethanol can be oxidized by $\mathrm{g}-\mathrm{C}_{3} \mathrm{~N}_{4} \cdot{ }^{50}$ This was evident from the lower optical purity of phenyl ethanol and the increased overoxidation to acetophenone.

Another interesting effect of formate was that the robustness of the overall reaction was significantly higher than when using methanol or no sacrificial electron donor. We attribute this to the hydroxyl radical scavenging activity of formate (vide infra). Methanol oxidation proceeds via methoxy radicals, which again may be assumed to have a detrimental influence on the stability of the biocatalyst. ${ }^{29}$

Overall, formate proved to be a suitable sacrificial electron donor for the reaction. We therefore systematically investigated the factors influencing the activity, selectivity, and robustness of the formate-driven photoenzymatic reaction system.

Increasing the concentration of formate had a positive effect on the reaction rate, selectivity, and robustness of the overall system (Figure 3). Hence, we concluded that the photo- 


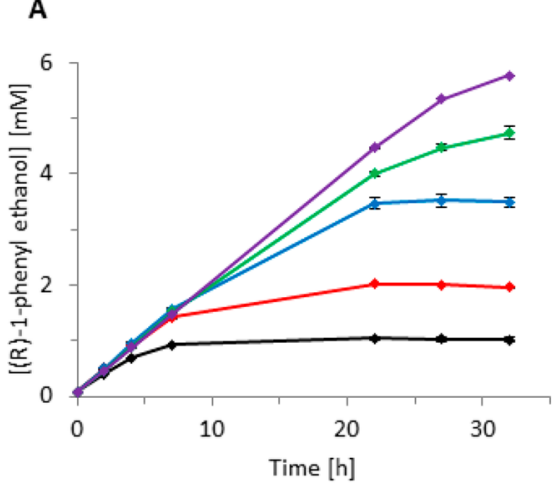

C

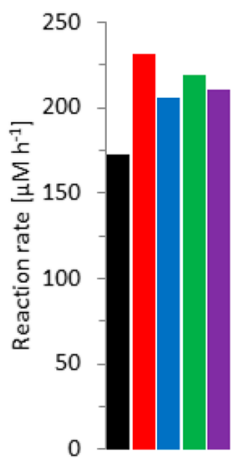

D

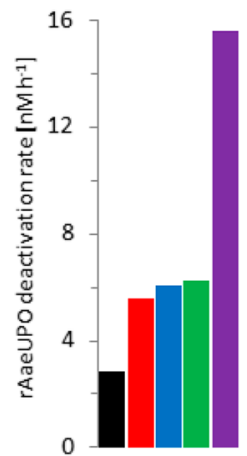

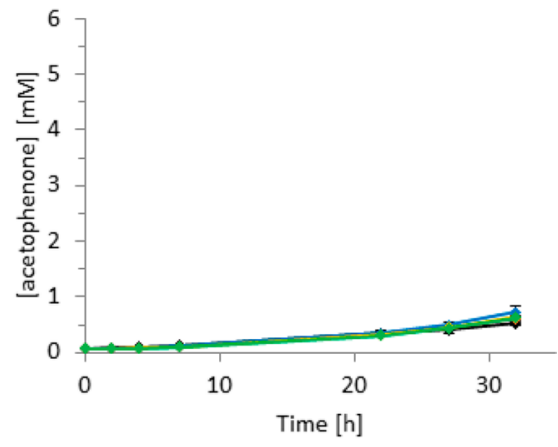

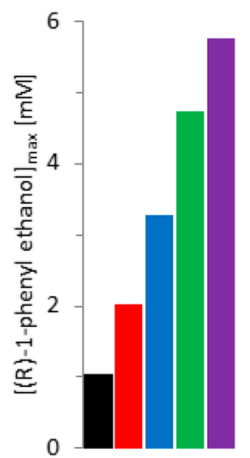

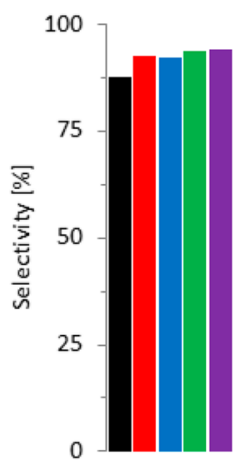

Figure 4. Influence of the rAaeUPO concentration on the performance of the photoenzymatic hydroxylation of ethylbenzene. A: time course of (R)-1-phenyl ethanol formation and B: time course of acetophenone formation. From these time courses, parameters such as reaction rate (C), rAaeUPO inactivation rate (D), maximal product concentration (E) and selectivity (F) were calculated. [rAaeUPO] $=20 \mathrm{nM}(\mathrm{black}), 50 \mathrm{nM}(\mathrm{red})$, $100 \mathrm{nM}$ (blue), $200 \mathrm{nM}$ (green) or $500 \mathrm{nM}$ (purple). General conditions: $\left[\mathrm{NaHCO}_{2}\right]=250 \mathrm{mM}$, [ethylbenzene] $=50 \mathrm{mM},\left[\mathrm{g}-\mathrm{C}_{3} \mathrm{~N}_{4}\right]=5 \mathrm{mg}$ $\mathrm{mL}^{-1}$, KPi buffer $\mathrm{pH} 7.0(100 \mathrm{mM}), 30^{\circ} \mathrm{C}$, magnetic stirring at $600 \mathrm{rpm}$, illumination by an Osram $200 \mathrm{~W}$ light bulb. Reactions were performed in independent duplicates.

catalytic oxidation of formate is the overall rate-limiting step in the reaction scheme.

The concentration of the biocatalyst also had a significant influence on the robustness of the overall reaction but hardly influenced the initial product formation rate (Figure 4). This supports our assumption that the photocatalytic $\mathrm{H}_{2} \mathrm{O}_{2}$ formation was rate-limiting and that undesired rAaeUPOinactivation by the photocatalyst represented the major undesired side reaction. Incubation of $\mathrm{g}-\mathrm{C}_{3} \mathrm{~N}_{4}$ with $\mathrm{rAaeUPO}$ in the darkness did not result in a significant inactivation of the biocatalyst (Figure S10), suggesting that photocatalytically generated reactive oxygen species are responsible for the enzyme inactivation observed (vide infra).

Next, we systematically varied the concentration of the photocatalyst (Figure 5). Very much to our surprise, the anticipated positive correlation between $\mathrm{g}-\mathrm{C}_{3} \mathrm{~N}_{4}$ concentration and $\mathrm{H}_{2} \mathrm{O}_{2}$ formation rate was less pronounced than expected. Moreover, rAaeUPO inactivation even decreased at higher g$\mathrm{C}_{3} \mathrm{~N}_{4}$ concentrations.

The most likely explanation for this observation is a selfshading effect of $\mathrm{g}-\mathrm{C}_{3} \mathrm{~N}_{4}$ (already at a photocatalyst concentration of $1 \mathrm{mg} \mathrm{mL}^{-1}$, the reaction mixture was turbid). Hence, because of a decreased light penetration at elevated photocatalyst concentrations, the majority of the photocatalyst remains inactive neither contributing to $\mathrm{H}_{2} \mathrm{O}_{2}$ generation nor to inactivating the biocatalyst.
The overall rate of the reaction was highest at neutral to slightly alkaline $\mathrm{pH}$ values (Figure S6). Currently, we are lacking a plausible explanation for this observation as the $\mathrm{H}_{2} \mathrm{O}_{2}$ generation rate of $\mathrm{g}-\mathrm{C}_{3} \mathrm{~N}_{4}$ was reported to be largely $\mathrm{pH}$ independent, ${ }^{53}$ whereas the highest activity of $\mathrm{rAaeUPO}$ may be expected in slightly acidic media. ${ }^{39}$ Similar trends have been observed before for $\mathrm{TiO}_{2}$, ${ }^{54}$ suggesting that the $\mathrm{pH}$-dependency of the complex $\mathrm{O}_{2}$-reduction mechanism may play an important role here. ${ }^{54}$

Also the morphology of the $\mathrm{g}-\mathrm{C}_{3} \mathrm{~N}_{4}$ catalyst had a significant influence on the overall reaction rate as well as the rAaeUPO inactivation rate. The form of $\mathrm{g}-\mathrm{C}_{3} \mathrm{~N}_{4}$ used so far are the socalled $\mathrm{g}-\mathrm{C}_{3} \mathrm{~N}_{4}$ sheets, obtained from calcination of urea. ${ }^{55}$ Further thermal treatment process leads to so-called amorphous $\mathrm{g}-\mathrm{C}_{3} \mathrm{~N}_{4}$, exhibiting a higher surface area. ${ }^{56} \mathrm{~A}$ preparation with lower specific surface area (bulk g- $\mathrm{C}_{3} \mathrm{~N}_{4}$ ) was obtained by starting the synthesis from melamine instead of urea (Figure S1). In line with our previous observations that the photocatalytic $\mathrm{H}_{2} \mathrm{O}_{2}$ generation is overall rate-limiting, we also observed a correlation between surface area and overall reaction rate (Figure 6). The same, however, was also true for the inactivation rate of $\mathrm{rAaeUPO}$, which increased with increasing surface area.

To evaluate the synthetic potential of the proposed photoenzymatic oxyfunctionalization system, we performed the reaction at semipreparative scale (Figure S7). To compensate for the high volatility of the starting material 


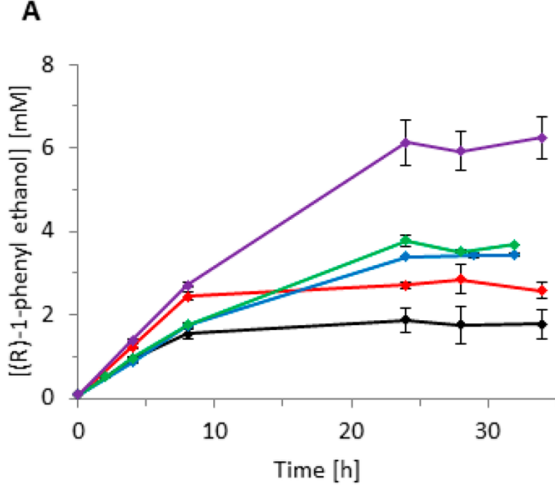

C

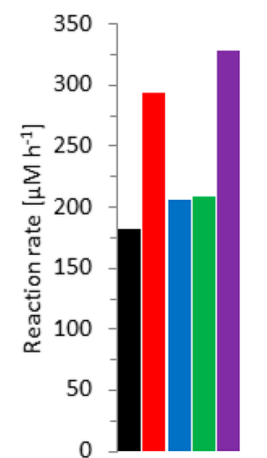

D

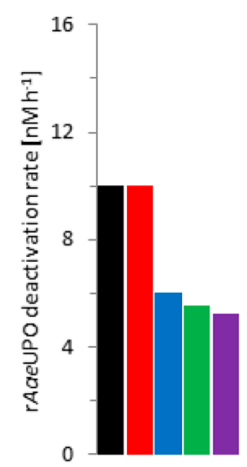

B

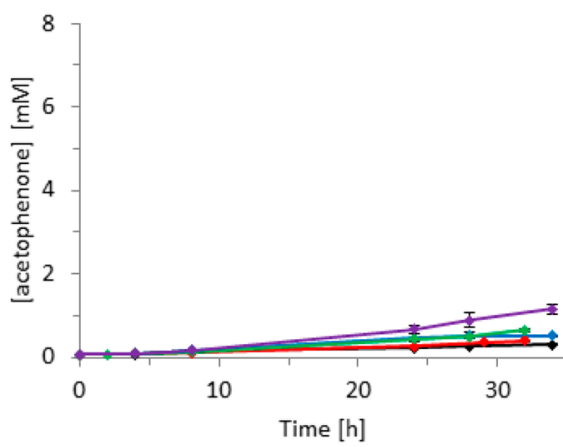

E
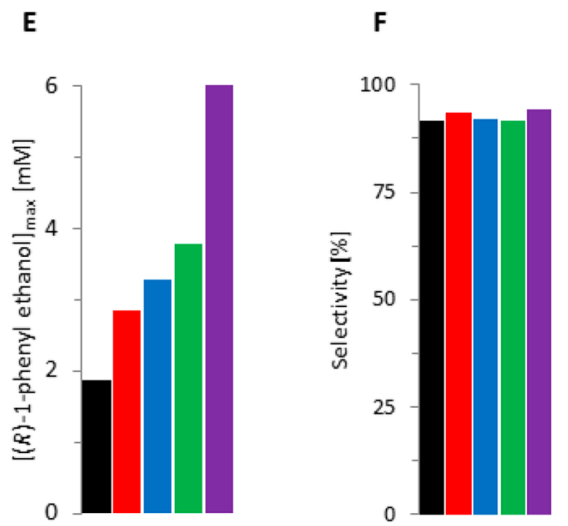

Figure 5. Influence of the $\mathrm{g}-\mathrm{C}_{3} \mathrm{~N}_{4}$ concentration on the performance of the photoenzymatic hydroxylation of ethylbenzene. (A) Time course of (R)-1-phenyl ethanol formation and (B) time course of acetophenone formation. From these time courses, parameters such as reaction rate (C), rAaeUPO inactivation rate (D), maximal product concentration (E) and selectivity (F) were calculated. [g-C $\left.\mathrm{N}_{4}\right]=1 \mathrm{mg} \mathrm{mL} \mathrm{m}^{-1}$ (black), $2.5 \mathrm{mg}$ $\mathrm{mL}^{-1}$ (red), $5 \mathrm{mg} \mathrm{mL}^{-1}$ (blue), $10 \mathrm{mg} \mathrm{mL}^{-1}$ (green), or $15 \mathrm{mg} \mathrm{mL}^{-1}$ (purple). General conditions: $\left[\mathrm{NaHCO}_{2}\right]=250 \mathrm{mM}$, [ethylbenzene] $=50$ $\mathrm{mM},[\mathrm{rAaeUPO}]=100 \mathrm{nM}, \mathrm{KPi}$ buffer $\mathrm{pH} 7.0(100 \mathrm{mM}), 30^{\circ} \mathrm{C}$, magnetic stirring at $600 \mathrm{rpm}$, illumination by an Osram $200 \mathrm{~W}$ light bulb. Reactions were performed in independent duplicates.

and the inactivation of the biocatalyst, both were replenished at intervals (see SI for details of the experimental procedure). In this experiment, $16.9 \mathrm{mM}$ of essentially pure (97.8\% ee) $(R)-1$ phenyl ethanol accumulated in the reaction mixture. From this, $42 \mathrm{mg}$ of the desired product was isolated. Admittedly, this is not yet a practical protocol for the synthesis of ( $R)$-1-phenyl ethanol. Especially, the high volatility of the reagents caused significant losses in the mass balance, which will have to be addressed in future, via improved experimental setups (circumventing the evaporation issue). Nevertheless, a respectable turnover number of more than 21000 for the biocatalyst was obtained in this experiment.

The major bottleneck of the current system is its poor robustness; generally within $24 \mathrm{~h}$, accumulation of $(R)-1$ phenyl ethanol ceased, which we attribute to the inactivation of the biocatalyst. As mentioned above, hydroxyl radicals may be assumed to be the primary products of $\mathrm{g}-\mathrm{C}_{3} \mathrm{~N}_{4}$-catalyzed water photo-oxidations. Indeed, using the spin trap method, ${ }^{57}$ we could confirm the occurrence of hydroxyl radicals (Figure 7). The short lifetime of $\cdot \mathrm{OH}$ in aqueous media ${ }^{58}$ suggests their predominant occurrence at the photocatalyst surface. We therefore also investigated whether $\mathrm{g}-\mathrm{C}_{3} \mathrm{~N}_{4}$ showed a tendency to absorb the biocatalyst. Indeed, we found that $\mathrm{rAaeUPO}$ and other proteins absorbed significantly to the polar surface of $\mathrm{g}$ $\mathrm{C}_{3} \mathrm{~N}_{4}$ (Figure 7). ${ }^{59}$ Here they are exposed to locally high concentrations of hydroxyl radicals, which sufficiently explains the rather poor robustness of the photoenzymatic reactions so far. As mentioned above, the absorption per se did not result in inactivation of rAaeUPO (Figure S10).

We hypothesized that spatial separation of rAaeUPO from the photocatalyst may enhance the stability of the enzyme under reaction conditions. Therefore, we tested this hypothesis by placing rAaeUPO into a dialysis bag, thereby preventing its direct contact with the photocatalyst (Figure 8). Here, the UPO and $\mathrm{g}_{-} \mathrm{C}_{3} \mathrm{~N}_{4}$ are contained, while both ethylbenzene as $\mathrm{H}_{2} \mathrm{O}_{2}$ could pass the membrane.

To our delight, physically separating the biocatalyst from the photocatalyst had the desired effect of stable product accumulation for more than 4 days. Compared with the previous experiments, this corresponds to an improvement by more than 4 times. However, this improvement came at the expense of a significantly decreased reaction rate, which is most likely to be attributed to diffusion limitations for the substrates over the dialysis membrane (Figure S4).

Overall, in this contribution we have expanded the scope of photoenzymatic oxyfunctionalization reactions to a broader range of heterogeneous photocatalysts. $\mathrm{g}-\mathrm{C}_{3} \mathrm{~N}_{4}$ appeared to be a good alternative to the established $\mathrm{TiO}_{2}$-based photocatalysts. Total turnover numbers of over 60.000 have been achieved for the rAaeUPO. The major limitations identified in this study were (1) the relatively low specific $\mathrm{H}_{2} \mathrm{O}_{2}$-generation rate of the photocatalysts and (2) the undesired inactivation of the biocatalysts at the photocatalyst surface. The first limitation can be addressed by further optimizing the catalyst and light 
A

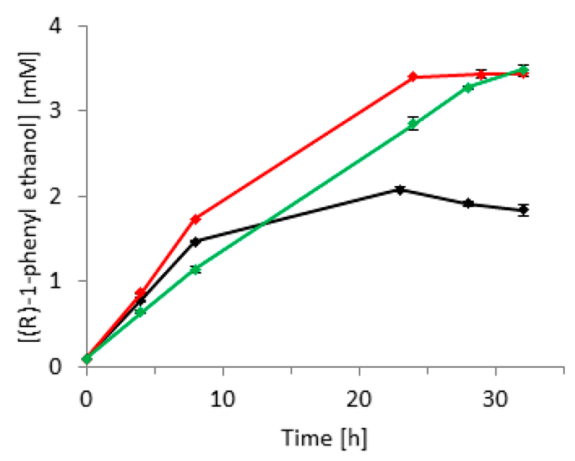

C

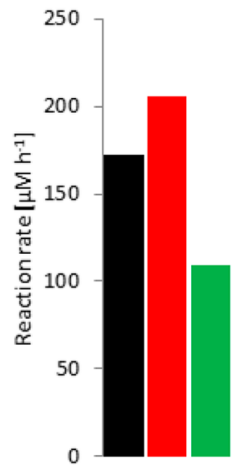

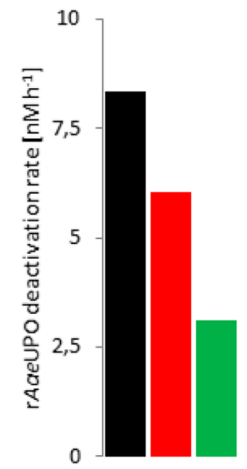

B

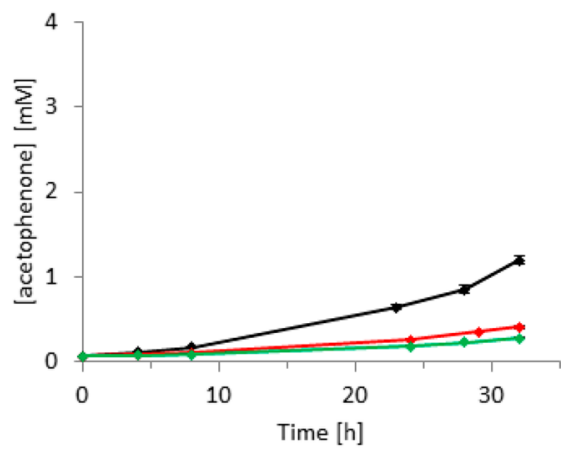

E

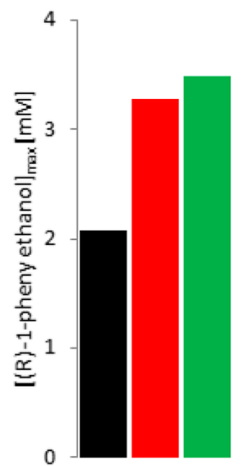

$\mathbf{F}$

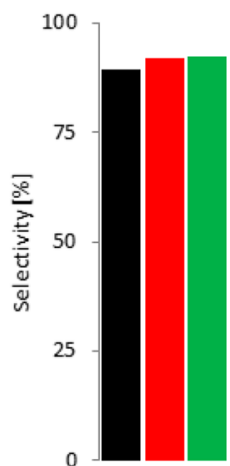

Figure 6. Influence of $\mathrm{g}-\mathrm{C}_{3} \mathrm{~N}_{4}$ morphology on the photoenzymatic hydroxylation of ethylbenzene. (A) Time course of (R)-1-phenyl ethanol formation and (B) time course of acetophenone formation. From these time courses, parameters such as reaction rate (C), rAaeUPO inactivation rate (D), maximal product concentration (E), and selectivity (F) were calculated. Amorphous g $^{-} \mathrm{C}_{3} \mathrm{~N}_{4}\left(\right.$ black), g- $\mathrm{C}_{3} \mathrm{~N}_{4}$ sheets (red), or g- $\mathrm{C}_{3} \mathrm{~N}_{4}$ bulk (green). Reaction conditions: $\left[\mathrm{NaHCO}_{2}\right]=250 \mathrm{mM}$, [ethylbenzene] $=50 \mathrm{mM},\left[\mathrm{g}-\mathrm{C}_{3} \mathrm{~N}_{4}\right]=5 \mathrm{mg} \mathrm{mL}{ }^{-1},[\mathrm{rAaeUPO}]=100 \mathrm{nM}, \mathrm{KPi}$ buffer pH 7.0 $(100 \mathrm{mM}), 30^{\circ} \mathrm{C}$, magnetic stirring at $600 \mathrm{rpm}$, illumination by an Osram $200 \mathrm{~W}$ light bulb. Reactions were performed in independent duplicates.
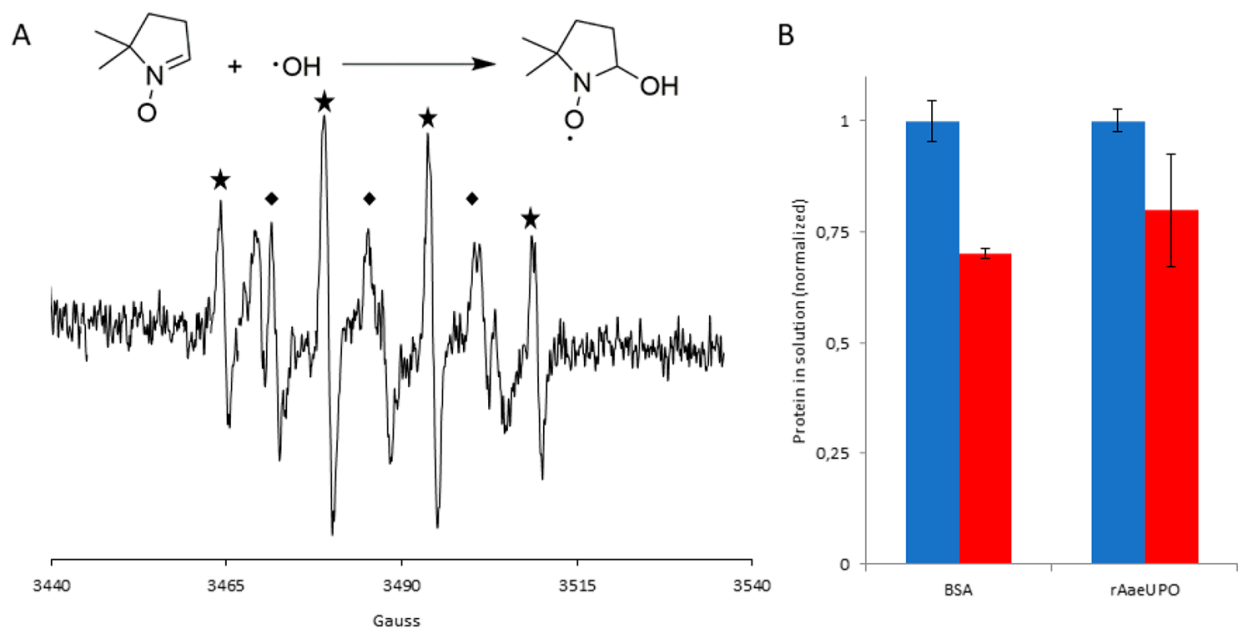

Figure 7. Investigating the molecular reasons for the decreased rAaeUPO-stability under process conditions. (A) Detection of hydroxyl radicals formed by irradiated $\mathrm{g}-\mathrm{C}_{3} \mathrm{~N}_{4}$ using the spin-trap method. Signals marked with a star $(\star)$ are assigned to the oxidation product of DMPO, 5,5dimethyl-2-oxopyrroline-1-oxyl (DMPOX). Signals marked with diamonds $(\diamond)$ belong to the spin adduct DMPO-OH. (B) Protein in solution before (blue) or after (red) incubation with $\mathrm{g}-\mathrm{C}_{3} \mathrm{~N}_{4}$ in the dark, for bovine serum albumin (BSA) or rAaeUPO.

intensity. The catalyst can be improved by chemically modifying the g- $\mathrm{C}_{3} \mathrm{~N}_{4}$ (e.g., doping with donor- or acceptortype dopants may be successful). ${ }^{60}$ Some preliminary results using $\mathrm{KOH}_{-}{ }^{61}$ or $\mathrm{Co}_{2} \mathrm{O}_{3}$-modified ${ }^{62} \mathrm{~g}^{-} \mathrm{C}_{3} \mathrm{~N}_{4}$ indeed demonstrated that doping can significantly influence the $\mathrm{H}_{2} \mathrm{O}_{2}$ - generation activity. Further systematic studies will validate this approach.

The second limitation (i.e., the oxidative inactivation of the biocatalyst by surface-borne reactive oxygen species) can be alleviated by physical separation. To circumvent the massive diffusion limitations observed in this double-heterogeneous 


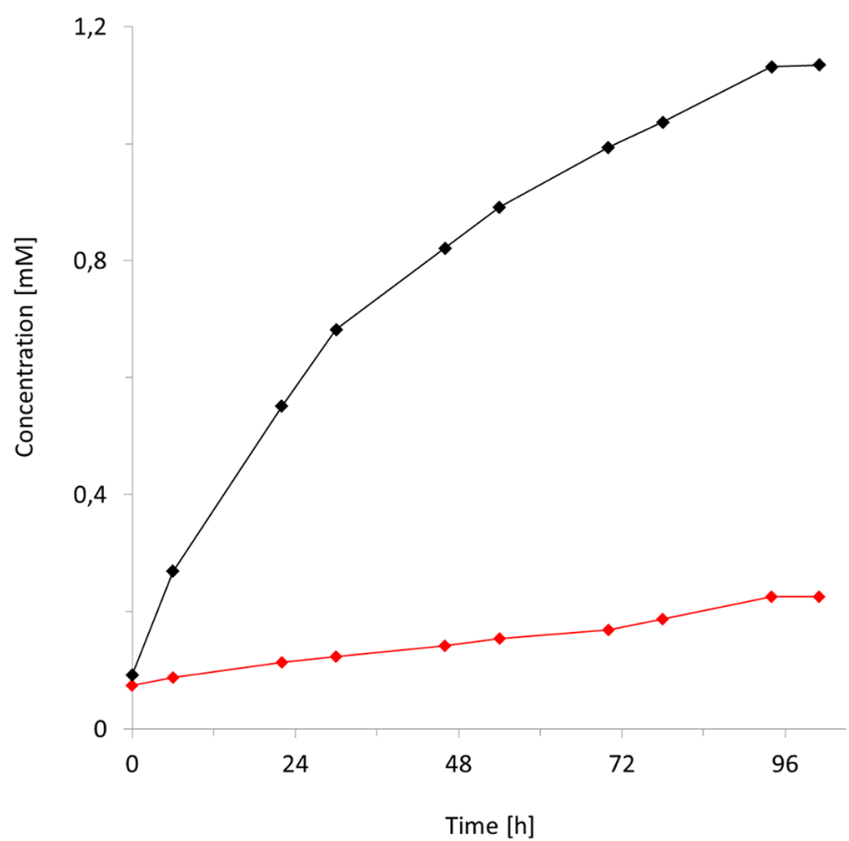

Figure 8. Time course of the photoenzymatic hydroxylation of ethylbenzene to (R)-1-phenyl ethanol (black) and overoxidation to acetophenone (red) using the dialysis bag approach. Conditions: 10 $\mathrm{mL}$ of reaction solution equally divided inside and outside the dialysis bag $(20 \mathrm{kDa}$ cutoff $)$. Inside the bag: $\left[\mathrm{NaHCO}_{2}\right]=250 \mathrm{mM}$, [ethylbenzene $]=50 \mathrm{mM},[\mathrm{rAaeUPO}]=100 \mathrm{nM}, \mathrm{KPi}$ buffer $\mathrm{pH} 7.0$ $(100 \mathrm{mM})$. Outside the bag: $\left[\mathrm{NaHCO}_{2}\right]=250 \mathrm{mM}$, [ethylbenzene] $=50 \mathrm{mM},\left[\mathrm{g}_{-} \mathrm{C}_{3} \mathrm{~N}_{4}\right]=5 \mathrm{mg} \mathrm{mL}^{-1}, \mathrm{KPi}$ buffer $\mathrm{pH} 7.0(100 \mathrm{mM})$. The reaction was performed once at room temperature while stirring at $600 \mathrm{rpm}$. The reaction solution was illuminated by a LIGHTNINGCURE spot light (Hamamatsu) at 50\% intensity with an UV filter.

reaction system, a linear plug-flow reactor concept may prove to be beneficial.

\section{EXPERIMENTAL SECTION}

Catalysts Preparation. rAaeUPO was produced by heterologous expression in Pichia pastoris performed following a previously reported procedure. ${ }^{38}$

g- $\mathbf{C}_{3} \mathbf{N}_{4}$ was synthesized either from urea or melamine as starting compound by heating it up in a furnace to $550{ }^{\circ} \mathrm{C}$ (heat ramp: $5{ }^{\circ} \mathrm{C} \mathrm{min}^{-1}$ ). In a typical procedure, from $10 \mathrm{~g}$ of urea, approximately $0.5 \mathrm{~g}$ of $\mathrm{g}-\mathrm{C}_{3} \mathrm{~N}_{4}$ sheets was obtained, whereas from $10 \mathrm{~g}$ of melamine, approximately $2 \mathrm{~g}$ of $\mathrm{g}-\mathrm{C}_{3} \mathrm{~N}_{4}$ bulk was obtained. Amorphous $\mathrm{g}-\mathrm{C}_{3} \mathrm{~N}_{4}$ was synthesized by further calcination of $\mathrm{g}-\mathrm{C}_{3} \mathrm{~N}_{4}$ sheets to $620{ }^{\circ} \mathrm{C}$ under an inert argon atmosphere. ${ }^{63}$

All other photocatalysts were either commercially available or prepared following literature procedures.

Reaction Setup. Unless stated differently, reactions were performed in $4 \mathrm{~mL}$ glass vials. Two milliliter reaction mixtures were stirred at $600 \mathrm{rpm}$ using a small stirring magnet $(6 \mathrm{~mm})$. The vials were placed around an incandescent white light bulb (Osram, 205W Halolux Ceram) at a distance of approximately $1 \mathrm{~cm}$. The water bath was continuously cooled at $30{ }^{\circ} \mathrm{C}$.

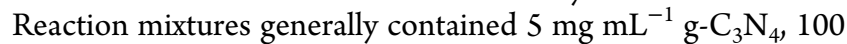
$\mathrm{nM}$ rAaeUPO, and $50 \mathrm{mM}$ ethylbenzene in a $100 \mathrm{mM} \mathrm{KPi}$ buffer at $\mathrm{pH}$ 7.0. Sacrificial electron donors were added to a concentration of $250 \mathrm{mM}$. Before use, the $\mathrm{g}-\mathrm{C}_{3} \mathrm{~N}_{4}$ was dispersed via sonication in $1 \mathrm{~mL}$ of the phosphate buffer. Samples were taken using a syringe and needle, keeping the reactors closed and preventing evaporation of the ethylbenzene. The reaction mixture $(200 \mu \mathrm{L})$ was taken and extracted with an aliquot of ethyl acetate containing $5 \mathrm{mM}$ octanol as internal standard. The mixtures were intensively mixed for $10 \mathrm{~s}$, centrifuged for $2 \mathrm{~min}$, and the organic phase was dried over magnesium sulfate and subsequently analyzed via achiral CG chromatography (CP-WAX 52 CB). Optical purities were determined using chiral GC (CP-Chirasil-Dex $\mathrm{CB})$.

Scale-Up Reaction. A $24 \mathrm{~mL}$ reaction, divided over $2 \mathrm{~mL}$ samples, was illuminated $80 \mathrm{~h}$ for increased product titers. The reaction was performed at $30{ }^{\circ} \mathrm{C}$ in a $\mathrm{KPi}$ buffer $(100 \mathrm{mM}, \mathrm{pH}$ 7.0) containing ethylbenzene $(50 \mathrm{mM}), \mathrm{g}-\mathrm{C}_{3} \mathrm{~N}_{4}\left(5 \mathrm{mg} \mathrm{mL}^{-1}\right)$, $\mathrm{rAaeUPO}(100 \mathrm{nM})$, and sodium formate $(250 \mathrm{mM})$. rAaeUPO (100 nM) was added to the reaction every $12 \mathrm{~h}$, and the ethylbenzene was replenished by adding $50 \mathrm{mM}$ extra substrate after $36 \mathrm{~h}$. At the end of the reaction, the compound was extracted with ethyl acetate, dried with $\mathrm{MgSO}_{4}$, and purified under reduced pressure at room temperature, also evaporating remaining substrate. The purity of the product was determined by ${ }^{1} \mathrm{H}$ NMR, while optical purity was determined using chiral GC (CP-Chirasil-Dex CB). NMR spectra were recorded on an Agilent 400 spectrometer in $\mathrm{CDCl}_{3}$. Chemical shifts are given in $\mathrm{ppm}$ with respect to tetramethylsilane. Coupling constants are reported as J-values in $\mathrm{Hz}$ ( $\mathrm{s}$ : singlet. d: doublet. t: triplet. q: quartet. m: multiplet. br: broad). ${ }^{1} \mathrm{H}$ NMR (400 MHz, $\left.\mathrm{CDCl}_{3}\right) \delta 7.40-7.26(\mathrm{~m}, 5 \mathrm{H}), 4.91$ (q, $J=$ $6.5 \mathrm{~Hz}, 1 \mathrm{H}), 1.82$ (br s, $1 \mathrm{H},-\mathrm{OH}), 1.51(\mathrm{~d}, J=6.4 \mathrm{~Hz}, 3 \mathrm{H})$. ${ }^{13} \mathrm{C}$ NMR $\left(100 \mathrm{MHz}, \mathrm{CDCl}_{3}\right) \delta 128.5,127.5,125.4,70.4$, 25.10 .

Data Manipulation. As the reaction rate, the initial formation rate of phenyl ethanol was taken, considering at least three data points. To estimate the enzyme deactivation rate, the following formula was used:

$$
\text { UPO deactivation rate }=\frac{[\mathrm{UPO}]_{0}}{\text { reaction time }}
$$

With:

$$
\text { reaction time }=\frac{[\max \text { phenylethanol }]}{\text { reaction rate }}
$$

The reaction selectivity was calculated by dividing the maximum amount of phenyl ethanol reached by the total amount of product formed in that same point in time.

$$
\text { selectivity }=\frac{[\text { max phenylethanol }]}{[\text { max phenylethanol }]+[\text { acetophenone }]_{t}}
$$

\section{ASSOCIATED CONTENT}

\section{Supporting Information}

The Supporting Information is available free of charge on the ACS Publications website at DOI: 10.1021/acscatal.9b01341.

Preparation of the catalysts, reaction setup, analytical data, and additional results (PDF)

\section{AUTHOR INFORMATION}

\section{Corresponding Authors}

*E-mail: m.m.c.h.vanschie@tudelft.nl.

*E-mail: f.hollmann@tudelft.nl.

ORCID ${ }^{\circ}$

Wuyuan Zhang: 0000-0002-3182-5107 
Chan Beum Park: 0000-0002-0767-8629

Bastien O. Burek: 0000-0002-2180-7458

Caroline E. Paul: 0000-0002-7889-9920

Miguel Alcalde: 0000-0001-6780-7616

Frank Hollmann: 0000-0003-4821-756X

\section{Notes}

The authors declare no competing financial interest.

\section{ACKNOWLEDGMENTS}

We thank The Netherlands Organization for Scientific Research for financial support through a VICI grant (No. 724.014.003) and by the European Union Project H2020-BBIPPP-2015-2-720297-ENZOX2. CEP acknowledges a VENI grant (No. 722.015.011).

\section{REFERENCES}

(1) Roduner, E.; Kaim, W.; Sarkar, B.; Urlacher, V. B.; Pleiss, J.; Gläser, R.; Einicke, W.-D.; Sprenger, G. A.; Beifuß, U.; Klemm, E.; Liebner, C.; Hieronymus, H.; Hsu, S.-F.; Plietker, B.; Laschat, S. Selective Catalytic Oxidation of C-H Bonds with Molecular Oxygen. Chem CatChem 2013, 5, 82-112.

(2) Dong, J.; Fernández-Fueyo, E.; Hollmann, F.; Paul, C.; Pesic, M.; Schmidt, S.; Wang, Y.; Younes, S.; Zhang, W. Biocatalytic Oxidation reactions - a Chemist's Perspective. Angew. Chem., Int. Ed. 2018, 57, 9238-9261.

(3) Wang, Y.; Lan, D.; Durrani, R.; Hollmann, F. Peroxygenases en route to becoming dream catalysts. What are the Opportunities and Challenges? Curr. Opin. Chem. Biol. 2017, 37, 1-9.

(4) Martínez, A. T.; Ruiz-Dueñas, F. J.; Camarero, S.; Serrano, A.; Linde, D.; Lund, H.; Vind, J.; Tovborg, M.; Herold-Majumdar, O. M.; Hofrichter, M.; Liers, C.; Ullrich, R.; Scheibner, K.; Sannia, G.; Piscitelli, A.; Pezzella, C.; Sener, M. E.; Kılıç, S.; van Berkel, W. J. H.; Guallar, V.; Lucas, M. F.; Zuhse, R.; Ludwig, R.; Hollmann, F.; Fernández-Fueyo, E.; Record, E.; Faulds, C. B.; Tortajada, M.; Winckelmann, I.; Rasmussen, J.-A.; Gelo-Pujic, M.; Gutiérrez, A.; del Río, J. C.; Rencoret, J.; Alcalde, M. Oxidoreductases on their way to Industrial Biotransformations. Biotechnol. Adv. 2017, 35, 815-831.

(5) Hofrichter, M.; Ullrich, R. Oxidations Catalyzed by Fungal Peroxygenases. Curr. Opin. Chem. Biol. 2014, 19, 116-125.

(6) Holtmann, D.; Hollmann, F. The Oxygen Dilemma: A Severe Challenge for the Application of Monooxygenases? ChemBioChem 2016, 17, 1391-1398.

(7) Valderrama, B.; Ayala, M.; Vazquez-Duhalt, R. Suicide Inactivation of Peroxidases and the Challenge of Engineering More Robust Enzymes. Chem. Biol. 2002, 9, 555-565.

(8) Burek, B. O. O.; Bormann, S.; Hollmann, F.; Bloh, J.; Holtmann, D. Hydrogen peroxide Driven Biocatalysis. Green Chem. 2019, 21, 3232-3249.

(9) Paul, C. E.; Churakova, E.; Maurits, E.; Girhard, M.; Urlacher, V. B.; Hollmann, F. In situ formation of $\mathrm{H}_{2} \mathrm{O}_{2}$ for P450 Peroxygenases. Bioorg. Med. Chem. 2014, 22, 5692-5696.

(10) Hollmann, F.; Schmid, A. Towards $\left[\mathrm{Cp} * \mathrm{Rh}(\text { bpy })\left(\mathrm{H}_{2} \mathrm{O}\right)\right]^{2+}$. promoted P450 Catalysis: Direct Regeneration of CytC. J. Inorg. Biochem. 2009, 103, 313-315.

(11) Karmee, S. K.; Roosen, C.; Kohlmann, C.; Lütz, S.; Greiner, L.; Leitner, W. Chemo-Enzymatic Cascade Oxidation in Supercritical Carbon Dioxide/Water Biphasic Media. Green Chem. 2009, 11, $1052-1055$

(12) Ranganathan, S.; Sieber, V. Recent Advances in the Direct Synthesis of Hydrogen Peroxide Using Chemical Catalysis-A Review. Catalysts 2018, 8, 379.

(13) Ranganathan, S.; Zeitlhofer, S.; Sieber, V. Development of a Lipase-Mediated Epoxidation Process for Monoterpenes in Choline Chloride-based Deep Eutectic Solvents. Green Chem. 2017, 19, 25762586.
(14) Ranganathan, S.; Sieber, V. Development of Semi-Continuous Chemo-Enzymatic Terpene Epoxidation: Combination of Anthraquinone Autooxidation and the Lipase-Mediated Epoxidation Process. React. Chem. Eng. 2017, 2, 885-895.

(15) Ranganathan, S.; Tebbe, J.; Wiemann, L.; Sieber, V. Optimization of the Lipase Mediated Epoxidation of Monoterpenes using the Design of Experiments-Taguchi Method. Process Biochem. 2016, 51, 1479-1485.

(16) Kohlmann, C.; Lütz, S. Electroenzymatic Synthesis of Chiral Sulfoxides. Eng. Life Sci. 2006, 6, 170-174.

(17) Lutz, S.; Steckhan, E.; Liese, A. First Asymmetric Electroenzymatic Oxidation Catalyzed by a Peroxidase. Electrochem. Commun. 2004, 6, 583-587.

(18) Horst, A. E. W.; Bormann, S.; Meyer, J.; Steinhagen, M.; Ludwig, R.; Drews, A.; Ansorge-Schumacher, M.; Holtmann, D. Electro-Enzymatic Hydroxylation of Ethylbenzene by the Evolved Unspecific Peroxygenase of Agrocybeaegerita. J. Mol. Catal. B: Enzym. 2016, 133, S137-S142.

(19) Holtmann, D.; Krieg, T.; Getrey, L.; Schrader, J. Electroenzymatic Process to Overcome Enzyme Instabilities. Catal. Commun. 2014, 51, 82-85.

(20) Getrey, L.; Krieg, T.; Hollmann, F.; Schrader, J.; Holtmann, D. Enzymatic Halogenation of the Phenolic Monoterpenes Thymol and Carvacrol with Chloroperoxidase. Green Chem. 2014, 16, 1104-1108.

(21) Krieg, T.; Huttmann, S.; Mangold, K.-M.; Schrader, J.; Holtmann, D. Gas Diffusion Electrode as Novel Reaction System for an Electro-Enzymatic Process with Chloroperoxidase. Green Chem. 2011, 13, 2686-2689.

(22) Pereira, P. C.; Arends, I.; Sheldon, R. A. Optimizing the Chloroperoxidase-Glucose Oxidase System: The Effect of Glucose Oxidase on Activity and Enantioselectivity. Process Biochem. 2015, 50, $746-751$.

(23) Tieves, F.; Willot, S. J.-P.; van Schie, M. M. C. H.; Rauch, M. C. R.; Younes, S. H. H.; Zhang, W.; Dong, J.; de Santos, P. G.; Robbins, J. M.; Bommarius, B.; Alcalde, M.; Bommarius, A.; Hollmann, F. Formate Oxidase (FOx) from Aspergillus oryzae: One Catalyst to Promote $\mathrm{H}_{2} \mathrm{O}_{2}$-Dependent Biocatalytic Oxidation Reactions. Angew. Chem., Int. Ed. 2019, 58, 7873-7877.

(24) Pesic, M.; Willot, S. J.-P.; Fernández-Fueyo, E.; Tieves, F.; Alcalde, M.; Hollmann, F. Multienzymatic in situ Hydrogen Peroxide Generation Cascade for Peroxygenase-Catalysed Oxyfunctionalisation Reactions. Z. f. Naturforsch. C 2019, 74, 101-104.

(25) Ma, Y.; Li, P.; Li, Y.; Willot, S. J.-P.; Zhang, W.; Ribitsch, D.; Choi, Y. H.; Zhang, T.; Verpoorte, R.; Hollmann, F.; Wang, Y. Natural Deep Eutectic Solvents as Multifunctional Media for the Valorisation of Agricultural Wastes. ChemSusChem 2019, 12, 13101315.

(26) Ni, Y.; Fernández-Fueyo, E.; Baraibar, A. G.; Ullrich, R.; Hofrichter, M.; Yanase, H.; Alcalde, M.; van Berkel, W. J. H.; Hollmann, F. Peroxygenase-Catalyzed Oxyfunctionalization Reactions Promoted by the Complete Oxidation of Methanol. Angew. Chem., Int. Ed. 2016, 55, 798-801.

(27) Willot, S. J. P.; Fernández-Fueyo, E.; Tieves, F.; Pesic, M.; Alcalde, M.; Arends, I. W. C. E.; Park, C. B.; Hollmann, F. Expanding the Spectrum of Light-Driven Peroxygenase Reactions. ACS Catal. 2019, 9, 890-894.

(28) Zhang, W.; Fernández-Fueyo, E.; Ni, Y.; van Schie, M.; Gacs, J.; Renirie, R.; Wever, R.; Mutti, F. G.; Rother, D.; Alcalde, M.; Hollmann, F. Selective Aerobic Oxidation Reactions using a Combination of Photocatalytic Water Oxidation and Enzymatic Oxyfunctionalizations. Nat. Catal. 2018, 1, 55-62.

(29) Zhang, W.; Burek, B. O.; Fernández-Fueyo, E.; Alcalde, M.; Bloh, J. Z.; Hollmann, F. Selective Activation of C-H Bonds by Cascading Photochemistry with Biocatalysis. Angew. Chem., Int. Ed. 2017, 56, 15451-15455.

(30) Choi, D. S.; Ni, Y.; Fernández-Fueyo, E.; Lee, M.; Hollmann, F.; Park, C. B. Photoelectroenzymatic Oxyfunctionalization on FlavinHybridized Carbon Nanotube Electrode Platform. ACS Catal. 2017, $7,1563-1567$. 
(31) Churakova, E.; Kluge, M.; Ullrich, R.; Arends, I.; Hofrichter, M.; Hollmann, F. Specific Photobiocatalytic Oxyfunctionalization Reactions. Angew. Chem., Int. Ed. 2011, 50, 10716-10719.

(32) Gulder, T.; Seel, C. J. Biocatalysis Fueled by Light: On the Versatile Combination of Photocatalysis and Enzymes. ChemBioChem 2019, DOI: $10.1002 /$ cbic. 201800806 .

(33) Seel, C. J.; Králík, A.; Hacker, M.; Frank, A.; König, B.; Gulder, T. Atom-Economic Electron Donors for Photobiocatalytic Halogenations. ChemCatChem 2018, 10, 3960-3963.

(34) Schmermund, L.; Jurkaš, V.; Özgen, F. F.; Barone, G. D.; Büchsenschütz, H. C.; Winkler, C. K.; Schmidt, S.; Kourist, R.; Kroutil, W. Photo-Biocatalysis: Biotransformations in the Presence of Light. ACS Catal. 2019, 9, 4115-4144.

(35) Goldstein, S.; Aschengrau, D.; Diamant, Y.; Rabani, J. Photolysis of Aqueous $\mathrm{H}_{2} \mathrm{O}_{2}$ : Quantum Yield and Applications for Polychromatic UV Actinometry in Photoreactors. Environ. Sci. Technol. 2007, 41, 7486-7490.

(36) Ullrich, R.; Hofrichter, M. The Haloperoxidase of the Agaric Fungus AgrocybeaegeritaHydroxylates Toluene and Naphthalene. FEBS Lett. 2005, 579, 6247-6250.

(37) Ullrich, R.; Nüske, J.; Scheibner, K.; Spantzel, J.; Hofrichter, M. Novel Haloperoxidase from the Agaric Basidiomycete AgrocybeaegeritaOxidizes Aryl Alcohols and Aldehydes. Appl. Environ. Microbiol. 2004, 70, 4575-4581.

(38) Molina-Espeja, P.; Ma, S.; Mate, D. M.; Ludwig, R.; Alcalde, M. Tandem-Yeast Expression System for Engineering and Producing Unspecific Peroxygenase. Enzyme Microb. Technol. 2015, 73-74, 2933.

(39) Molina-Espeja, P.; Garcia-Ruiz, E.; Gonzalez-Perez, D.; Ullrich, R.; Hofrichter, M.; Alcalde, M. Directed Evolution of Unspecific Peroxygenase from Agrocybeaegerita. Appl. Environ. Microbiol. 2014, 80, 3496-3507.

(40) Hirakawa, H.; Shiota, S.; Shiraishi, Y.; Sakamoto, H.; Ichikawa, S.; Hirai, T. Au Nanoparticles Supported on $\mathrm{BiVO}_{4}$ : Effective Inorganic Photocatalysts for $\mathrm{H}_{2} \mathrm{O}_{2}$ Production from Water and $\mathrm{O}_{2}$ under Visible Light. ACS Catal. 2016, 6, 4976-4982.

(41) Shi, N.; Cheng, W.; Zhou, H.; Fan, T.; Niederberger, M. Facile Synthesis of Monodisperse $\mathrm{Co}_{3} \mathrm{O}_{4}$ Quantum Dots with Efficient Oxygen Evolution Activity. Chem. Commun. 2015, 51, 1338-1340.

(42) Yin, Q. S.; Tan, J. M.; Besson, C.; Geletii, Y. V.; Musaev, D. G.; Kuznetsov, A. E.; Luo, Z.; Hardcastle, K. I.; Hill, C. L. A Fast Soluble Carbon-Free Molecular Water Oxidation Catalyst Based on Abundant Metals. Science 2010, 328, 342-345.

(43) Priebe, J. B.; Radnik, J.; Lennox, A. J. J.; Pohl, M. M.; Karnahl, M.; Hollmann, D.; Grabow, K.; Bentrup, U.; Junge, H.; Beller, M.; Bruckner, A. Solar Hydrogen Production by Plasmonic Au$\mathrm{TiO}_{2}$ Catalysts: Impact of Synthesis Protocol and $\mathrm{TiO}_{2}$ Phase on Charge Transfer Efficiency and $\mathrm{H}_{2}$ Evolution Rates. ACS Catal. 2015, 5, 2137-2148.

(44) Najafpour, M. M.; Pashaei, B. Nanoscale Manganese Oxide within Faujasite Zeolite as an Efficient and Biomimetic Water Oxidizing Catalyst. Dalton Trans. 2012, 41, 10156-10160.

(45) Maeda, K.; Ishimaki, K.; Okazaki, M.; Kanazawa, T.; Lu, D.; Nozawa, S.; Kato, H.; Kakihana, M. Cobalt Oxide Nanoclusters on Rutile Titania as Bifunctional Units for Water Oxidation Catalysis and Visible Light Absorption: Understanding the Structure-Activity Relationship. ACS Appl. Mater. Interfaces 2017, 9, 6114-6122.

(46) Boppana, V. B. R.; Jiao, F. Nanostructured $\mathrm{MnO}_{2}$ : an Efficient and Robust Water Oxidation Catalyst. Chem. Commun. 2011, 47, 8973-8975.

(47) Idris, A.; Hassan, N.; Mohd Ismail, N. S.; Misran, E.; Yusof, N. M.; Ngomsik, A.-F.; Bee, A. Photocatalytic Magnetic Separable Beads for Chromium (VI) Reduction. Water Res. 2010, 44, 1683-1688.

(48) Hamid, B. A. S.; Teh, S. J.; Lai, C. W. Photocatalytic Water Oxidation on $\mathrm{ZnO}$ : A Review. Catalysts 2017, 7, 93.

(49) Kim, H. W.; Ross, M. B.; Kornienko, N.; Zhang, L.; Guo, J.; Yang, P.; McCloskey, B. D. Efficient Hydrogen Peroxide Generation using Reduced Graphene Oxide-Based Oxygen Reduction Electrocatalysts. Nature Catal. 2018, 1, 282-290.
(50) Zhang, W.; Bariotaki, A.; Smonou, I.; Hollmann, F. VisibleLight-Driven Photooxidation of Alcohols using Surface-Doped Graphitic Carbon Nitride. Green Chem. 2017, 19, 2096-2100.

(51) Shiraishi, Y.; Kanazawa, S.; Sugano, Y.; Tsukamoto, D.; Sakamoto, H.; Ichikawa, S.; Hirai, T. Highly Selective Production of Hydrogen Peroxide on Graphitic Carbon Nitride $\left(\mathrm{g}-\mathrm{C}_{3} \mathrm{~N}_{4}\right)$ Photocatalyst Activated by Visible Light. ACS Catal. 2014, 4, 774-780.

(52) Burek, B. O.; Timm, J.; Bahnemann, D. W.; Bloh, J. Z. Kinetic Effects and Oxidation Pathways of Sacrificial Electron Donors on the Example of the Photocatalytic Reduction of Molecular Oxygen to Hydrogen Peroxide over Illuminated Titanium Dioxide. Catal. Today 2019, 335, 354-364.

(53) Li, S.; Dong, G.; Hailili, R.; Yang, L. L.; Li, Y.; Wang, F.; Zeng, Y.; Wang, C. Effective Photocatalytic $\mathrm{H}_{2} \mathrm{O}_{2}$ Production under Visible Light Irradiation at $\mathrm{g}-\mathrm{C}_{3} \mathrm{~N}_{4}$ Modulated by Carbon Vacancies. Appl. Catal., B 2016, 190, 26-35.

(54) Burek, B. O.; de Boer, S. R.; Tieves, F.; Zhang, W.; van Schie, M.; Bormann, S.; Alcalde, M.; Holtmann, D.; Hollmann, F.; Bahnemann, D. W.; Bloh, J. Z., Photoenzymatic Hydroxylation of Ethylbenzene Catalyzed by Unspecific Peroxygenase: Origin of Enzyme Inactivation and the Impact of Light Intensity and Temperature. ChemCatChem 2019, DOI: 10.1002/cctc.201900610.

(55) Zheng, Y.; Zhang, Z.; Li, C. A Comparison of Graphitic Carbon Nitrides Synthesized from Different Precursors through Pyrolysis. J. Photochem. Photobiol., A 2017, 332, 32-44.

(56) Kang, Y.; Yang, Y.; Yin, L.-C.; Kang, X.; Liu, G.; Cheng, H.-M. An Amorphous Carbon Nitride Photocatalyst with Greatly Extended Visible-Light-Responsive Range for Photocatalytic Hydrogen Generation. Adv. Mater. 2015, 27, 4572-4577.

(57) Dvoranová, D.; Barbieriková, Z.; Brezová, V. Radical Intermediates in Photoinduced Reactions on $\mathrm{TiO}_{2}$ (an EPR Spin Trapping Study). Molecules 2014, 19, 17279.

(58) Buxton, G. V.; Greenstock, C. L.; Helman, W. P.; Ross, A. B. Critical Review of Rate Constants for Reactions of Hydrated Electrons, Hydrogen Atoms and Hydroxyl Radicals $(\cdot \mathrm{OH} / \cdot \mathrm{O}-$ in Aqueous Solution. J. Phys. Chem. Ref. Data 1988, 17, 513-886.

(59) Hu, R.; Wang, X.; Dai, S.; Shao, D.; Hayat, T.; Alsaedi, A. Application of Graphitic Carbon Nitride for the Removal of $\mathrm{Pb}$ (II) and Aniline from Aqueous Solutions. Chem. Eng. J. 2015, 260, 469477.

(60) Moon, G.-H.; Fujitsuka, M.; Kim, S.; Majima, T.; Wang, X.; Choi, W. Eco-Friendly Photochemical Production of $\mathrm{H}_{2} \mathrm{O}_{2}$ through $\mathrm{O}_{2}$ Reduction over Carbon Nitride Frameworks Incorporated with Multiple Heteroelements. ACS Catal. 2017, 7, 2886-2895.

(61) Hu, S.; Li, F.; Fan, Z.; Wang, F.; Zhao, Y.; Lv, Z. Band gaptunable potassium doped graphitic carbon nitride with enhanced mineralization ability. Dalton Trans. 2015, 44, 1084-1092.

(62) Zhang, H.; Tian, W.; Zhou, L.; Sun, H.; Tade, M.; Wang, S. Monodisperse $\mathrm{Co}_{3} \mathrm{O}_{4}$ Quantum Dots on Porous Carbon Nitride Nanosheets for Enhanced Visible-Light-Driven Water Oxidation. Appl. Catal., B 2018, 223, 2-9.

(63) Son, E. J.; Lee, Y. W.; Ko, J. W.; Park, C. B. Amorphous Carbon Nitride as a Robust Photocatalyst for Biocatalytic Solar-to-Chemical Conversion. ACS Sustainable Chem. Eng. 2019, 7, 2545-2552. 